International Journal of

Journal of Humanities, Social Science, Public Administration and Management (HUSOCPUMENT)

Volume 1, Number 2, April 2021, pp. 32-37

https://www.publication.idsolutions.co.id/journals/index.php/husocpument/

DOI: https://doi.org/10.51715/husocpument.v1i2.58

\section{Digital Marketing Strategies To Increase Online Business Sales Through Social Media}

\author{
Niko Garuda Adiyono1, Tantri Yanuar Rahmat ${ }^{2}$, and Rina Anindita ${ }^{3}$
}

\author{
Faculty of Economic and Business, Esa Unggul University \\ E-mail: ${ }^{1}$ nikogaruda@gmail.com, ${ }^{2}$ tantri.yanuar@esaunggul.ac.id, ${ }^{3}$ rina.anindita@esaunggul.ac.id
}

\begin{abstract}
Technological developments have brought new media related to the internet. The internet is currently a necessity for many people around the world because with the internet, information can be conveyed quickly and easily. In the world of business is also entered by the internet. The internet creates something new, one way of marketing product. A businessman finds the latest marketing strategy by creating digital content for the products they offer and they will distribute it on social media so that more people and potential consumers will see and know about the product. Social Media is an application that provides video making features along with very interesting and easy to use effect features. That way, not a few online business people take advantage of the golden opportunity to use the application. Social Media as a platform to develop their business a through digital content.
\end{abstract}

Keywords - Digital Marketing, E-Marketing, Media Social

\section{Introduction}

In this modern era, the development of technology and information is increasingly advanced, which has changed the habits of many people. It can be seen by the number of internet users among parents, teenagers and children. Every day many people around the world who cannot be separated from the internet. Because with the internet, people can find the information they are looking for quickly. The internet is an advancement of technology that can affect various sectors such as social, cultural, educational, and economic. The number of internet users around the world is increasing every year. Indonesia is the 4th country with the most internet users in the world after China, India and America. This can be proven by data according to (Kominfo, 2017), states that $66.3 \%$ of Indonesians own smartphones and $45 \%$ of internet users. In 2020 internet users will increase to $73.7 \%$ of the population or the equivalent of 196.7 million, where almost all Indonesians use smartphones from a total population of 266.9 million (Central Statistics Agency, 2020 in the Association of Indonesian Internet Service Providers, 2020.). Then for internet user data using all media divided into computers, laptops, tablets and smartphones in 2019 amounted to $47.9 \%$ (BPS, 2020).

The use of smartphones by modern society, namely as a medium for transaction activities or shopping for daily needs which can be done by downloading the application. Applications that are downloaded by the community vary according to the needs of each individual. There are several applications that people use, including online shopping, online transportation and social media. But social media is the number 1 most downloaded application by most people. According to Philip Kolter and Kevin Keller in (Zuhri, Syarifudin, 2020) said that social media is a medium used by individuals to share text, images, sounds and videos of individual information. Social media users can communicate with each other, exchange information, share and many other activities. There are several examples of social media, namely Instagram, Youtube, Facebook, Whatssapp, Twitter and others (Rahmawati, Endis Citra Pradinda., 2020).

The presence of the internet has made activities more effective and efficient, both those of government agencies, companies, and individual communities. Along with the existence of social media, the formation of a new advertising model through the internet or online media platform which is then commonly referred to as digital marketing (Digital Marketing) is caused by the potential for the business market to become so broad. According to (Sudaryo et al., 2019), the definition of digital marketing is an effort to do marketing using electronic / internet devices with various marketing methods and social media in a timely, relevant and personal manner. There are various ways to get potential consumers to see the company's offerings, such as websites, blogs and social media. Digital marketing is a way to promote certain products 
using internet media such as social media (Facebook, Instagram, YouTube, line or other social media (Warmayana, 2018).

Digital marketing or marketing products or brands on social media platforms is packaged in an attractive way, namely by using various applications such as Instagram, WhatsApp, Line, Twitter, YouTube, and others. Most of the Indonesian people have downloaded and used the social media application which is used in the creation of interesting content and used as a platform by companies and individuals who are used in marketing their products. Social media platforms are useful for increasing sales of online businesses.

A businessman must have many marketing strategies in order to increase sales. Marketing is one of the most important activities in the business world. The importance of knowledge about online marketing so that online business sales run stably and competition is increasingly widespread, which requires entrepreneurs to have a marketing strategy in order to develop their business. The strategy for each sale is different, but nowadays, in modern times people have to make sure the conditions and desires of the people are easy and fast. From this, this research was conducted to provide information related to digital marketing using social media

\section{Literature Review}

Marketing is the process of distributing goods that have been produced by the company to consumers. According to (Kotler, 2018), marketing can run effectively and can increase profits by using customers, which is like having a good relationship with customers and can easily create value for customers, so that customers feel satisfied. According to the Big Indonesian Dictionary (KBBI), marketing is a method or process to market a product. The purpose of marketing is to meet the needs of consumers than other producers (Firmansyah, Anang 2019). The success of doing business in marketing is influenced by two factors, namely the product market and the consumer market. The consumer market will get a variety of brands. The success of doing business in marketing is influenced by two factors, namely the product market and the consumer market. The consumer market will get a variety of brands. One of the communications made by producers to consumers is advertising. Advertising in the modern era is the usual use of social media. The effectiveness of advertising can be measured using 3 criteria, namely: sales, remembrance and persuasion. The effectiveness of advertising by selling can be seen with research on the impact of sales, the impact of communication can have something to do with the effectiveness of advertising (Premita Lesawati, 2016). So the notion of marketing is an activity that takes advantage of the sales factor to bring in consumers, maintain good relationships and increase sales so that transactions that occur can be continuously and always connected to each other

\section{A. E-Marketing}

E-Marketing (Electronic Marketing) according to (Tjiptono, 2016) is a strategic process, developing, distributing, promoting, and setting prices for goods and services in target markets via the internet or digital devices such as smartphones. . At this time e-marketing is one of the promotional media that is considered effective and efficient, especially digital products, such as music, videos and the like. The growth of internet use in Indonesia in 2017 according to a survey from the Association of Indonesian Internet Service Users (APJII) in 2017 as shown in Figure 2. 143.26 million users which means an increase from 2016 which reached 132.7 million users from the total population of Indonesia's current population has reached 262 million people. This means that the growth penetration of internet users in Indonesia in 2017 was $54.68 \%$ compared to 2016 which was $51.03 \%$.

The increasing number of internet users in Indonesia has a huge impact on companies. Many companies have made changes with the marketing of their business, so that products easily reach the hands of the public. The company seeks to accelerate the distribution process by utilizing the internet as a means used to market and sell its products. This is because the internet network can connect computer users from one place to another in various parts of the world. Internet, which stands for internet and networking, is a collection of computer networks that communicate with each other from various types of computer networks (Dewi, Nugraha, 2017). Above, we have explained several types of online marketing, including e marketing, video marketing, social media marketing. The three types of online marketing have in common that they use the same media, namely the internet. The difference between the three types of online marketing is that e-marketing uses email as a tool to disseminate product information, video marketing uses video, for example YouTube, avlog, while social media used for marketing uses social media as a means of marketing products, social media include Facebook, Twitter, Instagram, WhatsApp, and online. With these differences, each type of online marketing will have its advantages and disadvantages. Of the three types of online marketing, social media marketing is the type often used by companies to market their products. 
Social media is a form of online marketing that uses the latest technology created by humans. Social media has several advantages, especially in its ability to communicate in two ways that are interactive, and make it easier for users to access various kinds of information. Marketing through social media (social media marketing) is a form of direct or indirect marketing to build awareness, and action for a brand or brand, business, person, or other entity and is done using tools from the social web, such as blogging, microblogging., social networking, social bookmarking, and content (Gunelius, 2011). Several social media that can be used like Facebook have.

Effectiveness is a measure that states how far the target (quantity, time and quality) has been achieved by management, where the target has been determined in advance. Marketing media that can be run by companies are now widely available and complete, these media can be selected by companies to market their products. With these many choices, companies can choose several media that can be used, or even a Literature Study of Product Marketing Effectiveness by Using an Online Marketing System using all of these media. Some of these media include Facebook, Instagram, Twitter, line, and others. How effective is the use of these media for the success of the company's online marketing. Several studies, including Prisma Lisawati, were conducted to test the effectiveness of advertising through social networks as a marketing strategy for UKMa products using the EPIC method (Emphaty, Persuasion, Impact, Communication).

The results of the study show that the strategy for marketing product advertisements through social networks is very effective. The analytical tool was then developed by A.C. Nielsen, which is in the form of an EPIC model, consists of the following four dimensions: The empathy dimension informs whether consumers like a form of marketing communication and describes how consumers see the relationship between a form of marketing communication and their personal. The persuasion dimension informs what a form of marketing communication can provide to strengthen the character of a brand, so that marketers gain an understanding of the impact of marketing communication on consumers' desire to buy. (Prisma Lisawati, 2017).

Companies are required to provide complete information about products, be able to lure consumers well, and be able to serve well (Kotler, 2017). One of the good communication tools at this point is the internet network that companies can take full advantage of. To be able to establish good communication with consumers, companies must be able to see the profile of the competition that is happening. The competition profile includes: 1. Who will compete today or in the future, 2. How do business competitors work, and what abilities do they have to encourage them to achieve, 3. How does each competitor place their position in the market, the last one is what competition is based on. (Hermawan Kertajaya, 2000). By knowing this profile, the communication that the company runs through online marketing will be successful in influencing consumers to buy its products. In addition, companies in carrying out communication should convey information clearly. Because the clear information factor has an influence on consumers to buy products offered by producers.

This is in line with the results of research conducted by Nia Purwati and her friends, who found that there was a strong influence between the clarity of information and the consumer's decision to buy online. Some of the media that can be used to run online marketing include Facebook, IG, and Twitter. If we look at the media Facebook as an online marketing tool, it has a strong enough dominance to run online marketing effectively. According to 2014 data, Facebook's monthly active use has now passed the 1.19 billion mark. Of these, 874 million of them access Facebook from mobile devices (Ita Suryani, 2014). With 126 Teguh Suriptoas the increasing number of Facebook users, it will provide convenience for companies to market their products. As time goes by, Instagram can be used to run online marketing. The data shows that there are 1 billion active Instagram users. (Kompas.com). This number is still below Facebook, but the ability of millennial Instagram is also good, because many young people are now more interested in using Instagram than Facebook. By knowing what the user profile is, the use of online marketing for the company will run effectively.

\section{A. Social Media}

According to (Drury Veby Zilfania, 2014) states that the use of social media is often used in marketing, public communication, offices or departments that are directly related to consumers or stakeholders. In business as well as social media is one of the channels that support communication in marketing merchandise quickly and profitably compared to selling directly to the market. The combination of social media with marketing is to support marketing performance along with technological and information developments. Social media marketing is a process that empowers individuals and companies to promote their websites, products or services online and through social channels to communicate with a much larger community that may not be available through traditional advertising channels. 
Social media marketing is a strategy for marketing activities using social media such as Facebook, Twitter, YouTube and so on. Social media is one of the most powerful ways to promote the products and services we have through internet marketing. The method is easy, simple, but has a very ordinary effect. In addition, social media marketing ear is a marketing technique or tactic that uses social media as a means to promote a product (link to an online business website page) or a service, or other product more specifically. Social media marketing focuses on the development and utilization of social media areas as a means or place to build the target market of online businesses. In the development of social media marketing, it is necessary to remember that business people must build groups or target markets with mutual respect and always communicate with the target market.

There are several social media marketing that are popular among the community, such as Facebook, Twitter, Pinterest, Youtube, Myspace, aDigg, Google Plus, Linkedin, Instagram and many others. In each social media that is used has different usage procedures, such as Instagram, for example, which can only share photos and videos that can be used. filled with links, descriptions, tags and hashtags. Another case with a facebook which has various features that can be used, such as creating anaFanpage, Group, aStatus Video, Link Status, Photo Status and others. Social media marketing techniques should be done by the owners of websites and online businesses, because social media marketing techniques are easier, cost efficient. The social work of media marketing is to build a market area and online business website links that are shared with various social media. The link that has been shared is able to provide an impact to attract many new visitors who are interested and who may become regular visitors of the online business website.

Social media marketing has various dimensions, namely as follows: 1. online communities are built by companies in order to offer products using social media. Where a group can create loyalty and encourage business development. 2. Interaction through Facebook and Twitter can provide a notification to all followers or a subject quickly and continuously. By using asocial networks can create interactions using the latest broadcasting, and consumers can easily get information. 3. sharing of Content Dimensions That are used as a medium for exchanging information, distributing, and obtaining content through social media. 4. Accessibility Social media can be accessed easily with relatively cheap costs, even if it does not cost money to use it. a In addition, social media also does not require skills or knowledge to access the site. 5. Credibility has a relationship about how a company makes and delivers messages clearly to consumers, motivates consumers to make purchases, builds credibility about what the company says and seeks to build emotional relationships with target applications and encourage consumer loyalty. In addition, social media is a platform for a business and can connect with consumers directly on a large scale and increase the confidence of participants in responding to suggestions or criticism from consumers.

\section{Method}

Method a The research used in this study is a systematic literature review (SLR). The method of systematic literature review is research that examines existing research and the researchers do not interact directly with the research subjects, but only examine secondary data or it can be said that the data generated from previous research. This study examines research journals that have the same focus (Irfannudin, 2019). This method is carried out by collecting data and information related to predetermined key words such as digital marketing, marketing and social media. The data used comes from national and international research journals, articles, magazines and supporting books. This literature study has the objective to find out the digital marketing strategies used to increase online-based sales through social media.

\section{Result and Discussion}

Social media is a plateform that is used to share problems and opinions. The marketing strategy of a good online businessman can communicate smoothly with their consumers or potential consumers so that the social media platform becomes a good marketing strategy because business players will easily share various information about their products through digital content. Socialamedia has positive and negative influences in business (Shankhdhar \& Abhimanyu, 2016)

a. Positive influence in online business

1. Through social media, business people are able to know the audience / market through a number of likes and dislikes

2. Helping business people in promoting merchandise

3. Can reach the market without a budget

4. Helping to increase insight to consumers in the market

5. Surpass your competitors with online networking 
b. Negative influence in online business

1. Negative comments can be accepted by business people

2. Risk of experiencing a failure

3. Some big business people have fallen victim to hackers.

4. The wrong online brand marketing strategy can hurt a company

5. Takes longer time than offline business

6. Most companies have a hard time measuring the results of social media advertising.

Therefore, in an online business, the ability to do digital marketing is required. Digital marketing is marketing that uses the internet in carrying out marketing activities to reach target consumers, besides that digital marketing can also be referred to as online marketing. The definition of online marketing is the marketing of products or services via the internet. There are two main points of the benefits of digital marketing described by, namely (Pwinterest,2015):

a. The promotion or marketing of a product if using digital marketing does not cost a lot, which means that the low cost alone can deliver the product to the general public and can reach potential buyers more widely compared to conventional marketing..

b. The advantage of using digital marketing is that information is conveyed more quickly to target consumers. Also related to the information presented to consumers or supervisors is more complete than conventional advertisements such as print media, television, and radio.

Other studies also mention some of the advantages of using digital marketing, namely (Nadara, at al. 2013):

a. The main advantage of social media marketing is that it relates to costs. Compared to other marketing, using social media marketing is quite low financial barrier. The majority of social media sites are free to access, create profiles and post information.

b. One of the most prominent new media phenomena is how to make improvements and create new forms of social interaction. People spend more than one-fourth of their time online engaged in communication activities (for example, e-mail, IM chat, and social networking), which is equivalent to the total time spent online for entertainment and general entertainment.

c. Interactivity can be broadly described as the extent to which users participate in modifying the form and content of a realatime-mediated environment.

\section{Conclussion}

Changes in people's behavior towards the presence of social media by the internet have forced business leaders to implement an online marketing system to determine the right marketing strategy in order to maintain and even expand the business they are running. Making digital content is an appropriate marketing strategy to be targeted at many people. Social media is one of the platforms for marketing digital content about a product they offer.

\section{References}

[1] Abhimanyu Shankhdhar, JIMS / Social media and businss http://www.pewinternet.org/2015/01/09/ social-media-update-2014/pi_2015-01-09_social-media_01/

[2] Dr. M. Neelamalar \& Ms. P. Chitra,Dept. of Media Sciences, Anna University Chennai, India, New media and society: A Study on the impact of socialnetworking sites on indian youth, Estudos em Comunicac, no6, 125-145

[3] Firdaus, M.F.R., Widodo. A. 2021. Pengaruh Pengetahuan Merek Hujau Dan Sikap Terhadap Merek Hijau Terhadap Niat Pembelian Hijau Pada Produk Tropicana Slim Di Kota Bandung. Jurnal Ilmiah MEA (Manajemen, Ekonomi, Dan Akuntansi), 5(2), 152-174.

[4] Firmansyah, Anang. 2019. Pemasaran Produk dan Merek (Planning \&Strategy).

[5] Ghulam Shabir,Yousef Mohammed Yousef Hameed,Ghulam Safdar, Syed Mohammed Farooq Shah Gilani,"the impact of social media on Youth: A case study of Bahawalpur City, Asian Journal of Social Sciences \& Humanities Vol. 3(4) November 2014

[6] Hanindharputri, M.A., Putra, I.K.A.M., 2019. Peran Influencer dalam Strategi Meningkatkan Promosi dari Suatu Brand (The Role of Influencer in Strategies to Increase Promotion of a Brand). Seminar Nasional Sandyakala 2019. 
[7] Hariyanti1, N.T., Wirapraja, P., 2018. Pengaruh Influencer Marketing Sebagai Strategi Pemasaran Digital Era Moderen (Sebuah Studi Literatur). Jurnal Eksekutif, 15 (1), J133-146

[8] https://www.kominfo.go.id/content/detail/5427/67-persen-pengguna-handphone-berbelanja-lewatsmartphone/0/sorotan_media

[9] Irfannuddin. 2019. Cara Sistematis Berlatih Meneliti (Merangkai Sistematika Penelitian Kedokteran dan Kesehatan). Jakarta Timur: Rayyana Komunikasindo. Jakarta: Qiara Media.

[10] Nadara, at al. 2013. Social Media Marketing SOCIAL Media Marketing: Advantages And Disadvantages

[11]Nurjannah, S. 2020. Strategi Promosi Akun Instagram @Surabaya_Foodies Pada Peningkatan Penjualan Kuliner. Universitas Islam Negeri Sunan Ampel: Surabaya.

[12] Poluan F.M.A.,Mandey., S., Ogi. I.W.J. 2019. Strategi Marketing Mix Dalam Meningkatkan Volume Penjualan (Studi Pada Minuman Kesehatan Instant Alvero). Jurnal EMBA, 7(3), 2969 - 2978.

[13] Rachmawati, F. 2018. Penerapan Digital Marketing Sebagai Strategi Komunikasi Pemasaran Terpadu Produk Usaha Kecil Dan Menengah (Ukm) Pahlawan Ekonomi Surabaya. Universitas Islam Negeri Sunan Ampel: Surabaya.

[14] Rahmawati, Endis Citra Pradinda., dkk. 2020. Media dan Perkembangan Budaya. Malang : Prodi Ilmu Komunikasi Universitas Muhammadiah Malang dan Intrans Publishing Group.

[15] Rapitasari, D. 2016. Digital Marketing Berbasis Aplikasi Sebagai Strategi Meningkatkan Kepuasan Pelanggan. Jurnal Cakrawala, 10 (2), 107 - 112.

[16] Retnasary, M., Setiawati S.R.,Fitriawati, D., Anggara, R,. 2019. Pengelolaan Media Sosial Sebagai Strategi Digital Marketing Pariwisata. Jurnal Kajian Pariwisata. 1(1), 77-83.

[17] Saputra, A. 2018. Survei Penggunaan Media Sosial Di Kalangan Mahasiswa Kota Padang Menggunakan Teori Uses And Gratifications. UPT Perpustakaan Universitas Andalas: Jurnal Dokumentasi dan Informasi, 40 (2) Desember 2019, Halaman : 207-216.

[18] Sudaryo, Yoyo., dkk 2020. Digital Marketing dan Fintech di Indonesia.Yogyakarta: Andi (Anggota AKPI).

[19] Supitro, T., 2018. Kajian Literatur Efektifitas Pemasaran Produk dengan Menggunakan Sistim Online Marketing di Era Disruption. Jurnal Ekonomi Syariah Indonesia, 8(2), 120-128.

[20] Untari, D , Fajariana, D E. 2018. Strategi Pemasaran Melalui Media Sosial Instagram (Studi Deskriptif Pada Akun@Subur_Batik). Widya Cipta, 2 (2).

[21] Waqas Tariq, Madiha Mehboob, M. Asfandyar Khan , FaseeUllah, The Impact of Social Media and Social Networks on Education and Students of Pakistan, IJCSI International Journal of Computer Science Issues, Vol. 9, Issue 4, No 3, July 2012

[22]Zuhri, Syaifudin dkk. 2020. Teori Komunikasi Massa dan Perubahan Masyarakat. Malang : Prodi Ilmu Komunikasi Universitas Muhammadiah Malang dan Intrans Publishing Group. 